\title{
Resin Glycosides from the Roots of Ipomoea tyrianthina and Their
}

\section{Biological Activity}

Gumersindo Mirón-López, ${ }^{\dagger}$ Maribel Herrera-Ruiz ${ }^{\ddagger}$, Samuel Estrada-Soto, ${ }^{\S}$ Francisco Aguirre-

Crespo, ${ }^{\S}$ Lorena Vázquez-Navarrete, ${ }^{\dagger}$ and Ismael León-Rivera ${ }^{* \dagger}$

${ }^{\dagger}{ }^{\S}$ Universidad Autónoma del Estado de Morelos.

${ }^{\ddagger}$ Instituto Mexicano del Seguro Social.

Email: ismaelr@ciq.uaem.mx

\section{List of Supporting Information}

Table S1. Percent (\% w/w) Yield of the Dichloromethane Extract from the Dried Roots of I. tyrianthina.

Table S2.- Principal Components in the Dicholoromethane Extract of I. tyrianthina

Table S3.- Anticonvulsant Effect of Different Compounds from I. tyrianthina on the Pentylenetetrazole-induced Convulsions in ICR Mice.

Figure S1. Effect produced by the ip administration of $10 \mathrm{mg} / \mathrm{kg}$ of tyrianthin 3 (3), tyrianthin $6(\mathbf{6})$, scammonin $1(\mathbf{8})$, and scammonin $2(\mathbf{9})$ on the immobility time of ICR mice exposed to the Swimming Forced paradigm.

Figure S2. Concentration-response curves showing the relaxant effects of tyrianthin $3(3)$, tyrianthin $6(\mathbf{6})$, scammonin $1(\mathbf{8})$, and scammonin $2(\mathbf{9})$ on the spontaneous contractions of the isolated rat ileum. 
Table S1.- Percent (\% w/w) Yield of the Dichloromethane Extract from the Dried Roots of $I$. tyrianthina.

\begin{tabular}{cccccc}
\hline Morelos & Morelos & Puebla & Puebla & Distrito Federal & Distrito Federal \\
(dryness) & (flowering) & (dryness) & (flowering) & (dryness) & (flowering) \\
\hline $13.5 \%$ & $13.8 \%$ & $12.2 \%$ & $13.3 \%$ & $10.9 \%$ & $13.7 \%$ \\
\hline
\end{tabular}

Table S2.- Principal Components in the Dichloromethane Extract of I. tyrianthina.

\begin{tabular}{ccl}
\hline \multicolumn{1}{c}{ Puebla } & \multicolumn{1}{c}{ Morelos } & \multicolumn{2}{c}{ Distrito Federal } \\
\hline tyrianthin $3(\mathbf{3}) 68.5 \%$, & tyrianthins $1(\mathbf{1}) 38.5 \%$ & tyrianthins $3(\mathbf{3}) 36.2 \%$ \\
scammonin $1(\mathbf{8}) 13.3 \%$ & and $6(\mathbf{6}) 15.4 \%$, and & and $6 \quad(\mathbf{6}) \quad 8.7 \quad \%$, \\
and $2(\mathbf{9}) 6.5 \%$, and & stansins $3(13.5 \%)$ and & scammonin $2(\mathbf{9}) 5.1 \%$, \\
orizabin I $(11.7 \%)$ & $5(5.8 \%)$ & and orizabins I (20.3\%) \\
& & and XVIII $(21.0 \%)$
\end{tabular}


Table S3. Anticonvulsant Effect of Different Compounds from I. tyrianthina on Pentylenetetrazole-induced Convulsions in ICR Mice.

\begin{tabular}{lccr}
\hline \multicolumn{1}{c}{ Compound } & $\begin{array}{c}\text { dose } \\
(\mathrm{mg} / \mathrm{kg})\end{array}$ & $\begin{array}{c}\text { onset of seizures } \\
(\text { seconds })^{a}\end{array}$ & $\begin{array}{c}\text { mortality protection } \\
(\%)\end{array}$ \\
\hline tyrianthin 6 (6) & 10.0 & $107.33 \pm 31.9$ & 33.33 \\
tyrianthin 6 (6) & 40.0 & $130.67 \pm 53.5$ & 83.33 \\
scammonin 1 $(\mathbf{8})$ & 10.0 & $101.50 \pm 29.7$ & 16.67 \\
scammonin 1 (8) & 40.0 & $650.67 \pm 121.8^{b}$ & 100.00 \\
scammonin 2 (9) & 10.0 & $277.83 \pm 80.2$ & 50.00 \\
scammonin 2 (9) & 40.0 & $413.17 \pm 91.0^{b}$ & 66.67 \\
diazepam & 1.0 & $00.0 \pm 00.0^{b}$ & 100.00 \\
tween 20, 1.0\% & $100 \mu \mathrm{L} / 10 \mathrm{~g}$ & $146.67 \pm 31.7$ & 0.00 \\
solution & & & \\
\hline
\end{tabular}

${ }^{a}$ Data presented as means $\pm \mathrm{SEM}^{\mathrm{a}}$ with $\mathrm{n}=7 .{ }^{b} p<0.05$ compared to control using ANOVA and post hoc Dunnet test. 


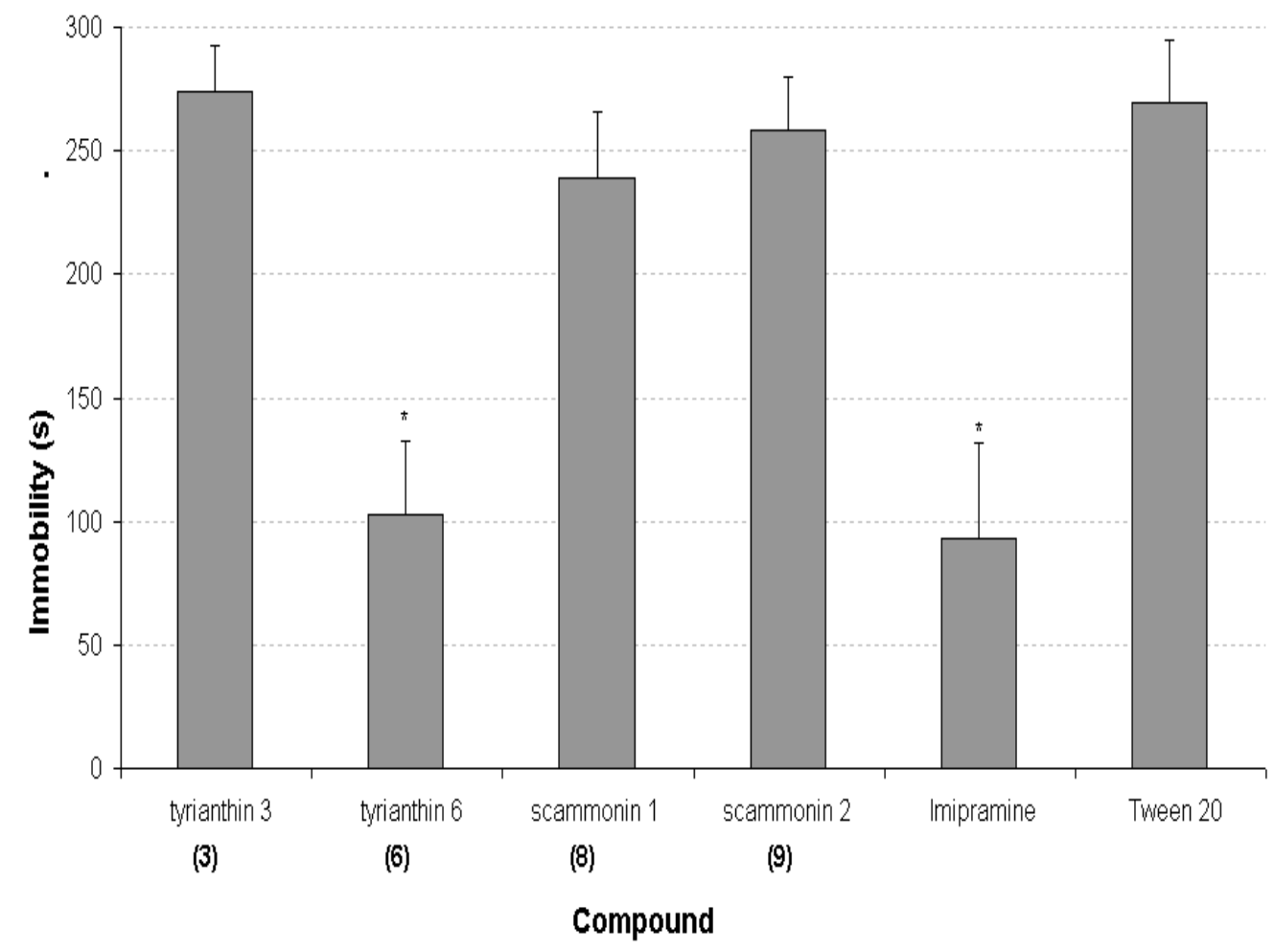

Figure S1. Effect produced by the ip administration of $10 \mathrm{mg} / \mathrm{kg}$ of tyrianthin 3 (3), tyrianthin $6(6)$, scammonin 1 (8), and scammonin 2 (9) on the immobility time of ICR mice exposed to the Swimming Forced paradigm. ${ }^{* *} p<0.001$ with on the ANOVA followed by post hoc Dunnet test (mean \pm S.D.). Imipramine, $15.0 \mathrm{mg} / \mathrm{kg}$; Tween $20,1 \%$ solution. 


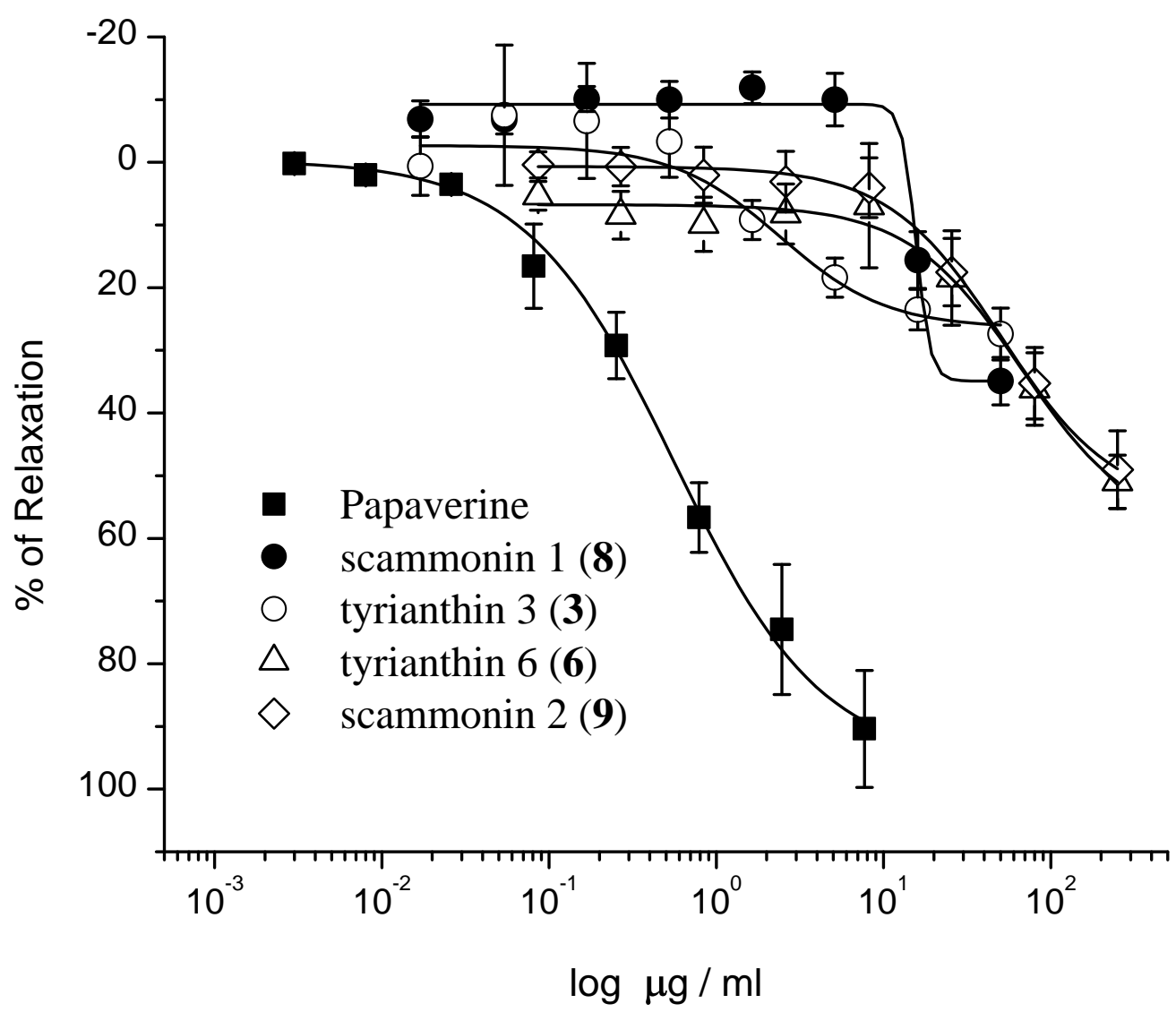

Figure S2. Concentration-response curves showing the relaxant effects of tyrianthin 3 (3), tyrianthin $6(\mathbf{6})$, scammonin $1(\mathbf{8})$, and scammonin 2 (9) on the spontaneous contractions of the isolated rat ileum. Values are expressed as the percentages of inhibition of contractile responses calculated as the mean from six data $\pm \mathrm{S}$. E. $(p<0.05)$. 